\title{
Co-occurrence of carbapenemase encoding genes in Acinetobacter baumannii, a dream or reality?
}

Linda Hadjadj, Sofiane Bakour and Jean-Marc Rolain * (1)

\begin{abstract}
Background: Acinetobacter baumannii is an important opportunistic pathogen that is rapidly evolving towards multidrug resistance and is responsible for life-threatening infections. Carbapenems are commonly used to treat $A$. baumannii infections but the emergence of carbapenemase encoding genes, such as bla OXA-23-like, bla OXA-24-like, bla $a_{\mathrm{OXA}-58-\mathrm{like}}$ and bla $a_{\mathrm{NDM}}$ has been reported. Moreover, several studies have reported the co-occurrence of two distinct carbapenemases in some isolates. The aim of the present study is to demonstrate whether the phenomenon of co-occurrence of two distinct carbapenemase encoding genes in a single isolate still exists.

Results: We studied six strains of $A$. baumannii including one harboring bla $a_{\mathrm{OXA}-23 \text {-like }}$ and bla $a_{\mathrm{OXA}-24-\text { like }}$ genes and five with bla $a_{O X A-23-l i k e}$ and bla $a_{\text {NDM }}$ genes. One colony of each strain was inoculated in sterile water and diluted ten-fold. Each dilution was cultivated on trypticase soy agar plates for $24 \mathrm{~h}$ at $37^{\circ} \mathrm{C}$ and the isolated bacteria were analyzed. For two of the six tested strains, we identified two different populations of $A$. baumannii, each with a different carbapenemase, genes encoding aminoglycoside modifying enzymes, resistance phenotype, and clonal type. In addition, the two different populations had the same aspect on the agar plate.
\end{abstract}

Conclusions: Here, we demonstrate that $A$. baumannii infections could be linked to multiple clones harboring different carbapenemase encoding genes in the same sample. In addition, we describe an easy method of verifying the presence of co-occurrence of carbapenemase in one isolate.

Keywords: Acinetobacter baumannii, Carbapenemase, Co-occurrence

\section{Background}

Acinetobacter baumannii is an important opportunistic Gram-negative bacteria pathogen that is rapidly evolving towards multidrug resistance. Worldwide, this bacterium is responsible for nosocomial infections and life-threatening infections [1]. The most common treatment is the use of carbapenems but extensive use of antimicrobial agents within hospitals has contributed to resistance against these antibiotics. The principal mechanism of resistance to carbapenems in A. baumannii is the production of OXA-type carbapenemases, such as OXA-23, OXA-24, and OXA-58 enzymes, and the new metallo- $\beta$-lactamase (MBL), New Delhi Metallo- $\beta$-lactamase 1 (NDM-1) [1].

\footnotetext{
* Correspondence: jean-marc.rolain@univ-amu.fr

Aix Marseille Univ, IRD, APHM, MEPHI, IHU Méditerranée Infection, Faculté de Médecine et de Pharmacie, 19-21 boulevard Jean Moulin, 13385 Marseille CEDEX 05, France
}

The location of the carbapenemase genes is not fixed, since some studies have described $b l a_{\text {OXA-23, }}, b l a_{\text {OXA-24 }}$ and $b l a_{\mathrm{OXA}-58}$ as chromosomal or plasmidic [2]. In epidemiologic studies, co-occurrences of carbapenemase genes, such as $b l a_{\mathrm{OXA}-23}-b l a_{\mathrm{OXA}-24,} b l a_{\mathrm{OXA}-23}-b l a_{\mathrm{NDM}}$, and $b l a_{\mathrm{OXA}-58}-b l a_{\mathrm{NDM}}$ have been described [3-8]. In $b l a_{\mathrm{OXA}-23}$ and $b l a_{\mathrm{NDM}}$ co-expressing Acinetobacter spp. strains, $b l a_{\mathrm{NDM}}$ can be acquired by plasmid $[4,9]$. However, it remains unclear whether and how these co-existing carbapenemase genes are expressed and how they contribute to drug resistance. The aim of our study was to provide an alternative explanation for the coexistence of $b l a_{\mathrm{OXA}}$ and $b l a_{\mathrm{NDM}}$ genes in A. baumannii. For this purpose, we describe an easy method of determining whether the co-occurrence of carbapenemase genes in such bacteria was "real" or whether it is due to the existence of different bacterial clones harboring different genes in the same sample. 


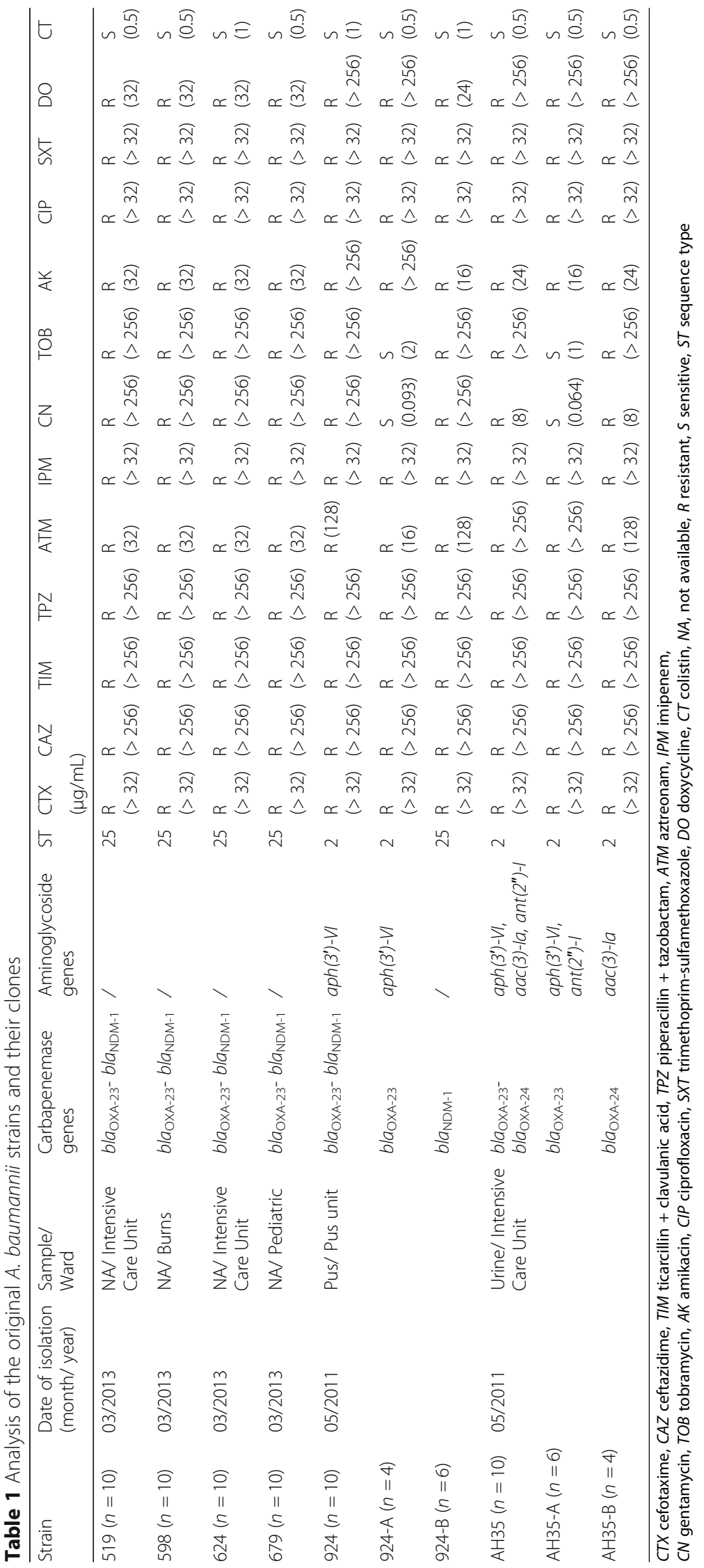




\section{Results}

Ten isolated colonies from the original diluted strain were analyzed and re-identified as A. baumannii using MALDI-TOF MS. Original strains 519, 598, 624, and 679 and all colonies tested were positive for both $b l a_{\mathrm{NDM}}$ and $b l a_{\mathrm{OXA}-23}$ genes before and after the limit dilution (Table 1). We therefore considered them as "true" strains with the co-occurrence of different carbapenemase genes. Original strain 924 was positive for both $b l a_{\mathrm{NDM}}$ and $b l a_{\mathrm{OXA}-23}$ genes. All 10 colonies obtained after the limit dilution were tested using real time PCR: six were positive only for the $b l a_{\mathrm{NDM}}$ gene while four were positive only for the $b l a_{\mathrm{OXA}-23}$ gene. The original strain belonged to the sequence type ST2 as were the clones carrying the $b l a_{\mathrm{OXA}-23}$ gene, whereas the clones harboring the $b l a_{\mathrm{NDM}}$ gene belonged to ST25 (Table 1).

Original strain AH35 was positive for both the $b l a_{\mathrm{OXA}-23}$ and $b l a_{\mathrm{OXA}-24}$ genes. Of the 10 colonies which were obtained after the limit dilution, six were positive only for the $b l a_{\text {OXA-23 }}$ gene while four were positive only for the bla $a_{\text {OXA-24 }}$ gene. All strains (the original strain and the clones obtained after dilution) belonged to ST2
(Table 1). For the original strain AH35, resistance to aminoglycosides was due to the production of aminoglycoside-modifying enzymes (AMEs) aph(3')-VI, $\operatorname{ant}(2 ")-I$ and $\operatorname{aac}(3)-I a$. The clone (AH35-A) which was susceptible to gentamycin and tobramycin harbored the bla $a_{\text {OXA-23, }} \operatorname{aph}\left(3^{\prime}\right)-V I$ and ant(2")-I genes whereas the clone (AH35-B) which was resistant to these antibiotics carried the $b l a_{\mathrm{OXA}-24}$ and $a a c(3)-I a$ genes. The original strain 924 was positive for the presence of the aph(3')-VI gene. The clone (924-A) which was resistant to amikacin harbored the $b l a_{\mathrm{OXA}-23}$ and $\operatorname{aph}\left(3^{\prime}\right)-V I$ genes; while no AME genes were found in the clone (924-B) carrying the bla $a_{\text {NDM }}$ gene and resistant to amikacin with relatively low MIC. Original strains AH35 and 924 were chimeras of their two clones. The results of the antibiotic susceptibility testing (AST) of the obtained clones after the limit dilution revealed two different resistance phenotypes according to the aminoglycosides presented in the different clones (Table 1). After sub-culturing the two original strains (924 and AH35) in the same conditions and the same TSA medium (Fig. 1), we observed no phenotypic differences in terms of size, form or color.

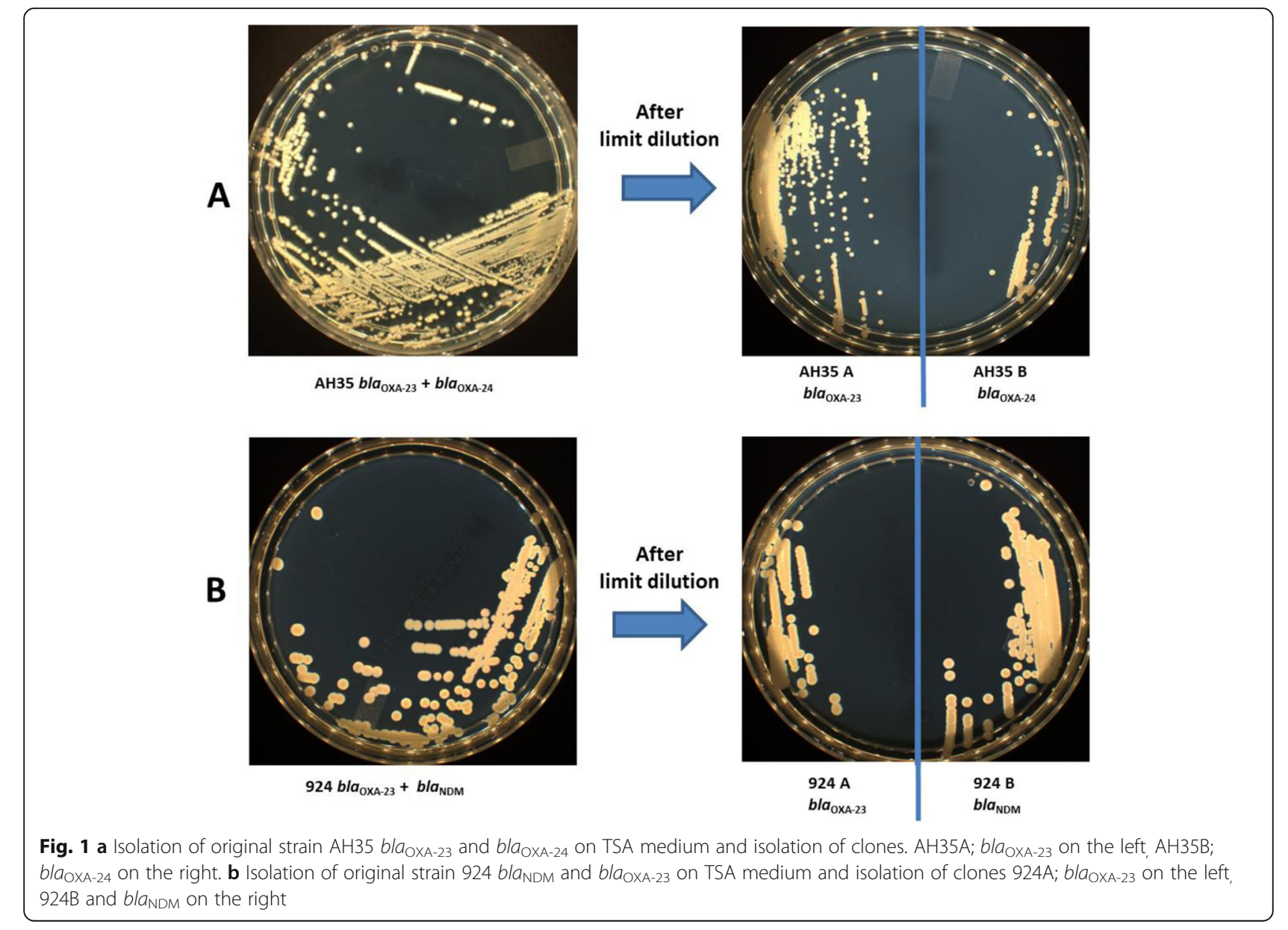




\section{Discussion}

Since $A$. baumannii is able to remodel its genome, antibiotic use and the host environment might impose selective forces that drive its rapid adaptive evolution. Microscale genome modification has been revealed through the analysis of single nucleotide polymorphisms (SNPs) between A. baumannii strains isolated from the same patient. This modification can lead the emergence of resistance and to different sequence typing by modifying a single allele [10]. However, this explanation cannot be applied to our case, because ST2 and ST25 have only two common alleles. Mutations in five alleles would be a substantial evolution. Moreover, this cannot be an evolution of a clone because the presence of different carbapenemase-encoding genes was also observed.

Another phenomenon, referred to as small colony variants (SCVs), mostly described in Staphylococcus aureus, was also identified from one sample with different susceptibility to antibiotics from the parent strain [11]. SCVs can cause latent and recurrent infections and have been observed in many genera of bacteria, including Gram-negative bacteria such as Pseudomonas aeruginosa [12]. In our case, the populations are morphologically identical and do not have the aspect of small colony variants.
The presence of different populations of a same species in the same sample had been already described in S. aureus [13]. Similarly to our study, different clones with different resistance phenotypes, such as methicillin-susceptible and methicillin-resistant $S$. aureus strains could be isolated from the same sample by increasing the number of colonies tested for each sample [14].

$B l a_{\mathrm{OXA}-23}, b l a_{\mathrm{OXA}-24}$ and $b l a_{\mathrm{NDM}}$ can be located either on the chromosome or plasmid. For this reason, we tend to believe that co-occurrence with other resistance genes is due to the presence of different genes in the same strain. However, another explanation could be the presence of a polyclonal population of $A$. baumannii from the same sample. These populations are morphologically undetectable with the naked eye. Although the number of strains studied was limited, our work represents the proof of concept that co-occurrence of carbapenemases in $A$. baumannii could be due to multiple clones.

\section{Conclusion}

In this work, we demonstrated that from one sample and from an original "chimera" strain with two carbapenemase genes which were highly resistant to antibiotics, we were able to isolate two less resistant strains with

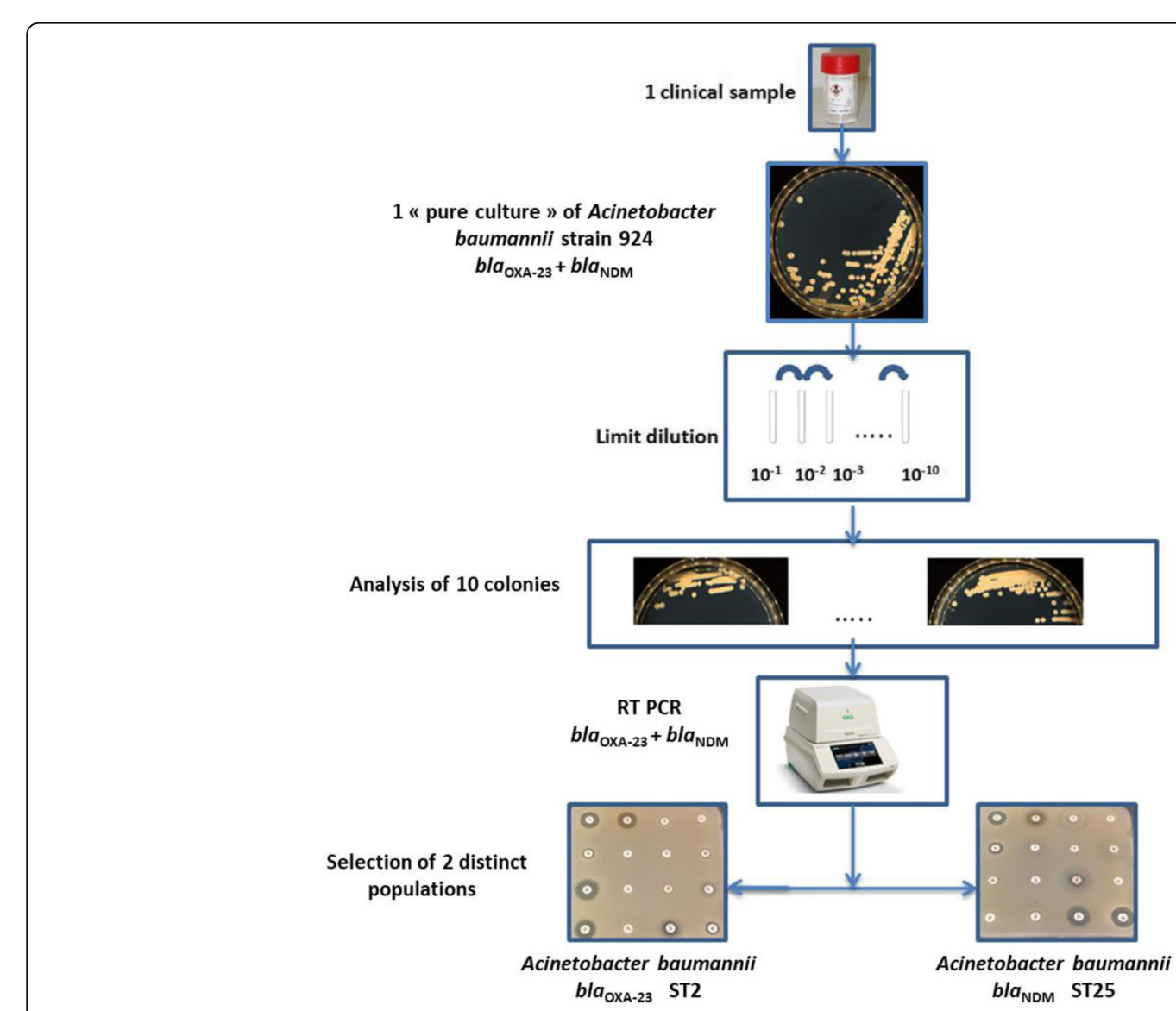

Fig. 2 Example of the study of the strain 924 
only one gene encoding for carbapenems resistance. The presence of different clonal types and different genes encoding aminoglycoside modifying enzymes in each clone is also evidence of polyclonal coexistence in a single sample.

Another option, in similar case to this current study, is the coexistence in a single sample of different clones harboring one carbapenemase encoding gene as well as different resistance genes. In addition, this study has strong implications for clinical practice. The use of only one colony from one sample to conduct AST may omit another population which may be more resistant.

\section{Methods}

Six A. baumannii strains $(924,519,598,624$, and 679$)$ isolated from two Algerian hospitals were studied; five $A$. baumannii co-expressed $b l a_{\mathrm{OXA}-23}$ and $b l a_{\mathrm{NDM}}$ genes recovered from a hospital in Algiers, and one A. baumannii (AH35) co-expressed $b l a_{\mathrm{OXA}-23}$ and $b l a_{\mathrm{NDM}}$ gene isolated from a urine sample in an intensive care unit in a hospital in Setif (Table 1). These clinical isolates were taken for the purpose of this study. Identification was confirmed using matrix-assisted laser desorption and ionization timeof-flight mass spectrometry (MALDI-TOF) (Microflex, Brüker Daltonics, Bremen, Germany) [15].

For each strain, one colony was inoculated in sterile water and diluted ten-fold to isolate a single clone. Each dilution was cultivated on Trypticase Soy Agar (TSA) plates for $24 \mathrm{~h}$ at $37{ }^{\circ} \mathrm{C}$ and isolated bacterial were analyzed. Antibiotic susceptibility was determined by minimum inhibitory concentrations (MICs) using broth microdilution method (Biocentric) for colistin and using the E-test method (bioMérieux) for others antibiotics tested in accordance with the European Committee on Antimicrobial Susceptibility Testing (EUCAST). Real time PCR was performed to verify the presence of the $b l a_{\mathrm{OXA}-23}, b l a_{\mathrm{OXA}-24}$ and $b l a_{\mathrm{NDM}}$ genes $[16,17]$. Standard PCR amplification was carried out using primers for amplification of the aph(3')-VI, ant(2")-I, aac(3)-Ia, $a a c\left(6^{\prime}\right)-I b$ and $\operatorname{armA}$ genes [18]. Clonal types of the isolates were determined using multilocus sequence typing (MLST) in line with the Pasteur schemes (https:// pubmlst.org/abaumannii/). Each stage of the materials and methods section is summarized in Fig. 2.

\footnotetext{
Abbreviations

AME: Aminoglycoside-modifying enzyme; AST: Antibiotic susceptibility testing; EUCAST: European Committee on Antimicrobial Susceptibility Testing; MALDI-TOF: Matrix-assisted laser desorption and ionization time-offlight mass spectrometry; MBL: Metallo- $\beta$-lactamase; MIC: Minimum inhibitory concentration; MLST: Multilocus sequence typing; SCV: Small colony variants; SNP: Single nucleotide polymorphism; TSA: Trypticase soy agar
}

\section{Funding}

This work was supported by the French Government under the « Investissements d'avenir » program managed by the Agence Nationale de la Recherche, (reference: Méditerranée Infection 10-IAHU-03). This work was supported by Région Provence Alpes Côte d'Azur and European funding FEDER PRIMI.

\section{Availability of data and materials}

All data generated or analysed during this study are included in this published article.

\section{Authors' contributions}

LH wrote the manuscript, performed experiments, and analyzed the data. SB provided the strains and helped draft the manuscript. JMR conceived the study, participated in its design and coordination, and helped draft the manuscript. All authors read and approved the final manuscript.

Ethics approval and consent to participate

Not applicable.

\section{Consent for publication}

Not applicable.

\section{Competing interests}

The authors declare that they have no competing interests.

\section{Publisher's Note}

Springer Nature remains neutral with regard to jurisdictional claims in published maps and institutional affiliations.

Received: 11 December 2017 Accepted: 28 August 2018

Published online: 05 September 2018

\section{References}

1. Kempf M, Rolain J-M. Emergence of resistance to carbapenems in Acinetobacter baumannii in Europe: clinical impact and therapeutic options. Int J Antimicrob Agents [Internet]. 2012 [cited 2017 Aug 29];39:105-114 Available from: http://www.ncbi.nlm.nih.gov/pubmed/22113193.

2. Poirel L, Bonnin RA, Nordmann P. Genetic basis of antibiotic resistance in pathogenic Acinetobacter species. IUBMB Life [Internet]. 2011 [cited 2017 Oct 28];63:1061-1067. Available from: http://doi.wiley.com/https://doi.org/ 10.1002/iub.532

3. Zhou S, Chen X, Meng X, Zhang G, Wang J, Zhou D, et al. "Roar" of blaNDM-1 and "silence" of blaOXA-58 co-exist in Acinetobacter pittii. Sci Rep [Internet]. 2015 [cited 2017 Oct 28];5:8976. Available from: http://www. nature.com/articles/srep08976

4. Zhang R, Hu Y-Y, Yang X-F, Gu D-X, Zhou H-W, Hu Q-F, et al. Emergence of NDM-producing non-baumannii Acinetobacter spp. isolated from China. Eur J Clin Microbiol Infect Dis [Internet]. 2014 [cited 2017 Oct 28];33:853-860. Available from: http://link.springer.com/10.1007/s10096-013-2024-4

5. Krizova L, Bonnin RA, Nordmann P, Nemec A, Poirel L. Characterization of a multidrug-resistant Acinetobacter baumannii strain carrying the blaNDM-1 and blaOXA-23 carbapenemase genes from the Czech Republic. J Antimicrob Chemother [Internet]. 2012 [cited 2017 Oct 28];67:1550-1552. Available from: https://academic.oup.com/jac/article-lookup/doi/10.1093/jac/ dks064

6. Bakour S, Touati A, Bachiri T, Sahli F, Tiouit D, Naim M, et al. First report of 165 rRNA methylase ArmA-producing Acinetobacter baumannii and rapid spread of metallo- $\beta$-lactamase NDM-1 in Algerian hospitals. J Infect Chemother [Internet]. 2014 [cited 2017 Oct 28];20:696-701. Available from: http://linkinghub.elsevier.com/retrieve/pii/S1341321X14002517

7. Bakour S, Kempf M, Touati A, Ait Ameur A, Haouchine D, Sahli F, et al. Carbapenemase-producing Acinetobacter baumannii in two university hospitals in Algeria. J Med Microbiol [Internet]. 2012 [cited 2017 Oct 28];61: 1341-1343. Available from: http://jmm.microbiologyresearch.org/content/ journal/jmm/10.1099/jmm.0.045807-0

8. Ramoul A, Loucif L, Bakour S, Amiri S, Dekhil M, Rolain J-M. Co-occurrence of blaNDM-1 with blaOXA-23 or blaOXA-58 in clinical multidrug-resistant Acinetobacter baumannii isolates in Algeria. J Glob Antimicrob Resist [Internet]. 2016 [cited 2017 Oct 21]:6:136-141. Available from: http// linkinghub.elsevier.com/retrieve/pii/S2213716516300510 
9. Feng Y, Yang P, Wang X, Zong Z. Characterization of Acinetobacter johnsonii isolate XBB1 carrying nine plasmids and encoding NDM-1, OXA-58 and PER1 by genome sequencing. J Antimicrob Chemother [Internet]. 2016 [cited 2017 Oct 28];71:71-75. Available from: https://academic.oup.com/jac/articlelookup/doi/10.1093/jac/dkv324

10. Wen H, Wang K, Liu Y, Tay M, Lauro FM, Huang H, et al. Population dynamics of an Acinetobacter baumannii clonal complex during colonization of patients. Dunne WM, editor. J Clin Microbiol [Internet]. 2014 [cited 2017 Oct 28];52:3200-3208. Available from: http://jcm.asm.org/lookup/doi/10. 1128/JCM.00921-14

11. Chuard C, Vaudaux PE, Proctor RA, Lew DP. Decreased susceptibility to antibiotic killing of a stable small colony variant of Staphylococcus aureus in fluid phase and on fibronectin-coated surfaces. J Antimicrob Chemother [Internet]. 1997 [cited 2017 Oct 28];39:603-608. Available from: http://www. ncbi.nlm.nih.gov/pubmed/9184359.

12. Proctor RA, von Eiff C, Kahl BC, Becker K, McNamara P, Herrmann M, et al. Small colony variants: a pathogenic form of bacteria that facilitates persistent and recurrent infections. Nat Rev Microbiol [Internet]. 2006 [cited 2017 Oct 28];:4295-305. Available from: http://www.nature.com/doifinder/ 10.1038/nrmicro1384

13. Votintseva AA, Miller RR, Fung R, Knox K, Godwin H, Peto TEA, et al. Multiple-strain colonization in nasal carriers of Staphylococcus aureus. J Clin Microbiol [Internet]. American Society for Microbiology; 2014 [cited 2017 Nov 14];52:1192-1200. Available from: http://www.ncbi.nlm.nih.gov/ pubmed/24501033.

14. Fetsch A, Roesler U, Kraushaar B, Friese A. Co-colonization and clonal diversity of methicillin-sensitive and methicillin-resistant Staphylococcus aureus in sows. Vet Microbiol [Internet]. 2016 [cited 2017 Nov 14];185:7-14. Available from: http://www.ncbi.nlm.nih.gov/pubmed/26931385.

15. Seng P, Drancourt M, Gouriet F, La Scola B, Fournier P-E, Rolain JM, et al. Ongoing revolution in bacteriology: routine identification of bacteria by matrix-assisted laser desorption ionization time-of-flight mass spectrometry. Clin Infect Dis [Internet]. 2009 [cited 2017 Oct 28];49:543-551. Available from: https://academic.oup.com/cid/article-lookup/doi/10.1086/600885

16. Diene SM, Bruder N, Raoult D, Rolain J-M. Real-time PCR assay allows detection of the New Delhi metallo- $\beta$-lactamase (NDM-1)-encoding gene in France. Int J Antimicrob Agents [Internet]. 2011 [cited 2017 Oct 28]:37:544546. Available from: http://linkinghub.elsevier.com/retrieve/pii/ S0924857911001038

17. Mesli E, Berrazeg M, Drissi M, Bekkhoucha SN, Rolain J-M. Prevalence of carbapenemase-encoding genes including New Delhi metallo- $\beta$-lactamase in Acinetobacter species, Algeria. Int J Infect Dis [Internet]. 2013 [cited 2017 Oct 28];17:e739-e743. Available from: http://linkinghub.elsevier.com/ retrieve/pii/S1201971213001173

18. Bakour S, Touati A, Sahli F, Ameur AA, Haouchine D, Rolain J-M. Antibiotic resistance determinants of multidrug-resistant Acinetobacter baumannii clinical isolates in Algeria. Diagn Microbiol Infect Dis [Internet]. 2013 [cited 2017 Oct 28];76:529-531. Available from: http://www.ncbi.nlm.nih.gov/ pubmed/23688522.

Ready to submit your research? Choose BMC and benefit from:

- fast, convenient online submission

- thorough peer review by experienced researchers in your field

- rapid publication on acceptance

- support for research data, including large and complex data types

- gold Open Access which fosters wider collaboration and increased citations

- maximum visibility for your research: over $100 \mathrm{M}$ website views per year

At $\mathrm{BMC}$, research is always in progress.

Learn more biomedcentral.com/submissions 